\title{
Can pyroxenes be liquidus minerals in the kimberlite magma?
}

\author{
Maya B. Kamenetsky ${ }^{1}$, Vadim S. Kamenetsky ${ }^{1}$, Alexander V. Sobolev², Alexander V. \\ Golovin $^{3}$ \\ ${ }^{1}$ CODES and School of Earth Sciences, University of Tasmania, Hobart, TAS, Australia \\ ${ }^{2}$ Vernadsky Institute of Geochemistry, Moscow, Russia \\ ${ }^{3}$ Institute of Geology and Mineralogy, Novosibirsk, Russia
}

Introduction. Group-I "basaltic” or “serpentinecalcite" kimberlites are believed to originate from a carbonated ultramafic magma (Harris et al., 2004; Kopylova et al., 2007; le Roex et al., 2003; Mitchell, 1986; Price et al., 2000). Crystallisation of such magmas during and after emplacement results in abundant olivine phenocrysts, followed by phlogopite, perovskite, Cr-Ti-Fe oxides, calcite, monicellite, serpentine and some other minor minerals that altogether compose the groundmass of kimberlitic rocks. Pyroxene minerals were never found as phenocrystic or groundmass phases, and only clinopyroxene sometimes occurs in experiments with inferred parental kimberlite compositions (Edgar and Charbonneau, 1993). Moreover, pyroxenes, if released from mantle xenoliths entrained by kimberlite magmas on ascent, are thought to be largely consumed by the magma, because their rare presence as macrocrysts in kimberlite rocks does not match their high abundance (20-60\%) in the xenoliths. On the other hand, all terrestrial ultramafic and basaltic melt are characteristically pyroxene-saturated, in particular after initial olivine + chromite crystallisation that increases $\mathrm{SiO}_{2}$ and $\mathrm{CaO}$ contents of the magma. Thus, the absence of pyroxenes in kimberlites is a mystery. Two possibilities arise: 1) the pyroxenes are completely destroyed by common alteration or 2) the kimberlite melt, unlike other silicate mafic magmas, never crystallises the pyroxenes. We tested both possibilities using samples of unaltered Udachnaya-East kimberlite, Russia (Kamenetsky et al., 2004) and studies of pyroxene inclusions in the olivine macrocrysts and phenocrysts, and made inferences on their relationships to the kimberlite magma.

Results. Extensive search for pyroxenes in mineral separates and polished slides revealed presence of rare resorbed clinopyroxene and orthopyroxene macrocrysts (up to several $\mathrm{mm}$ in size). Both minerals are completely absent in the groundmass assemblage, however, they are found as inclusions in olivine. Where such inclusions occur in olivine fragments and contact with the groundmass, they show strong resorption and partial replacement by monticellite (Fig. 1).

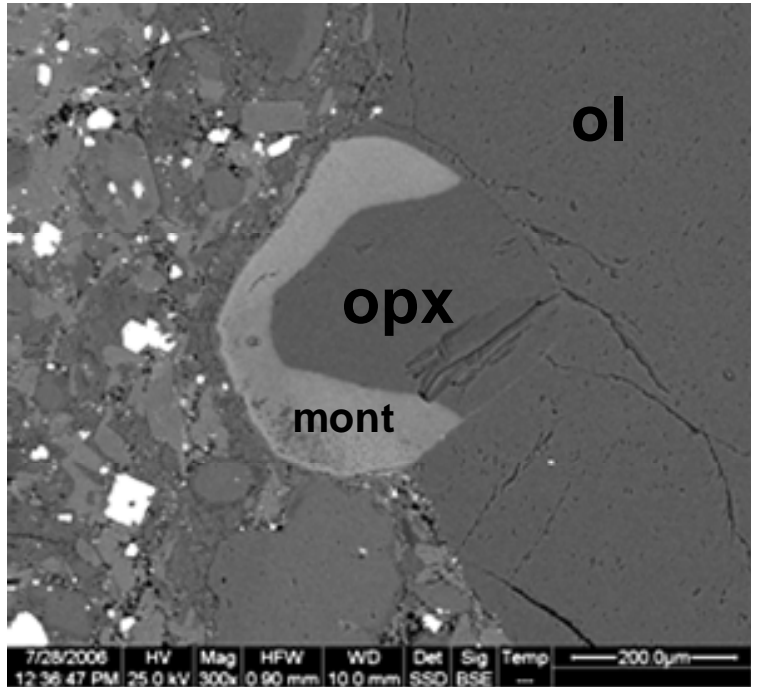

Fig. 1. Monticellite (mont) replacing orthopyroxene inclusion (opx) at the broken surface of olivine macrocryst (ol) at the contact with the kimberlite groundmass (Udachnaya-East pipe).

Inclusions of orthopyroxene (Mg\# 88-92) occur mainly in the rims of groundmass olivine-II $\left(\mathrm{FO}_{86-91}\right)$ in clusters of several (10-30) round and euhedral grains. A common association of low-Ca pyroxene in the rims includes numerous inclusions of the carbonate-chloride melt and fluid, and $\mathrm{CO}_{2}$-rich bubbles adhered to surfaces of pyroxene crystals (Fig. 2; Sobolev et al., 1989). The orthopyroxene inclusions are in equilibrium

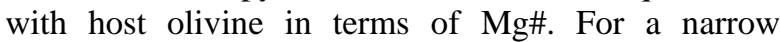

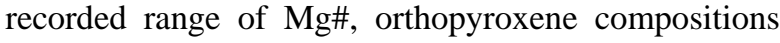
are strongly variable for all elements (in wt\%: $\mathrm{SiO}_{2}$ 55.9-58, $\mathrm{Na}_{2} \mathrm{O}$ 0.11-0.28, $\mathrm{TiO}_{2}$ 0.04-0.23, $\mathrm{Al}_{2} \mathrm{O}_{3}$ 0.61.3, $\mathrm{CaO} 0.75-1.65$ and $\mathrm{Cr}_{2} \mathrm{O}_{3}$ 0.05-0.54), and no clear correlations with $\mathrm{Mg \#}$ exist (except $\mathrm{Al}_{2} \mathrm{O}_{3}$ and $\mathrm{Cr}_{2} \mathrm{O}_{3}$ ). Compositions of orthopyroxene inclusions and orthopyroxene from peridotite nodules in the Udachnaya pipe kimberlite (e.g. Sobolev, 1977) do not overlap in terms of Mg\# (92.0-93.3 mol\% in the latter), but are broadly similar in other elements. It is most likely that orthopyroxene was unstable in the kimberlite melt, but could have originated in small quantities owing to the local reaction between olivine and $\mathrm{CO}_{2}$ fluid $\left(2 \mathrm{SiO}_{4}^{-4}+2 \mathrm{CO}_{2} \rightarrow \mathrm{Si}_{2} \mathrm{O}_{6}{ }^{-4}+2 \mathrm{CO}_{3}{ }^{-2}\right)$. However, we cannot exclude mantle origin of 
orthopyroxene inclusions in olivine and their mutual

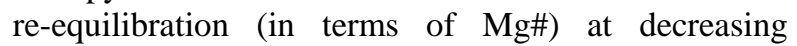
temperature and pressure.

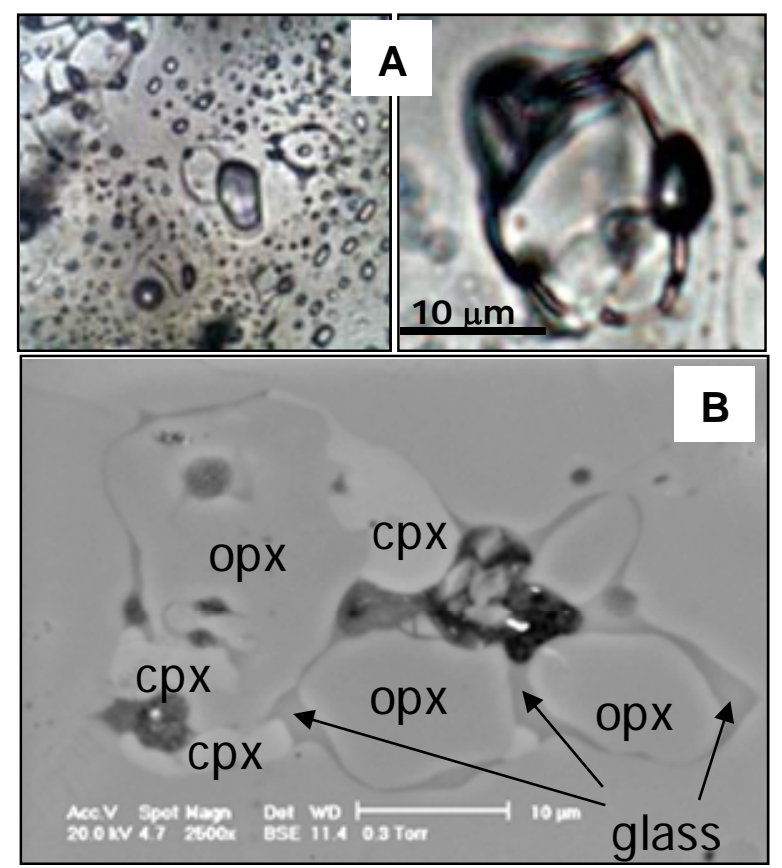

Fig. 2. Orthopyroxene inclusions in kimberlitic olivine associated with carbonate melt and $\mathrm{CO}_{2}$ fluid bubbles (A) and clinopyroxene and silicate melt films (B).

Inclusions of clinopyroxene in the Udachnaya-East olivine are restricted to macrocrysts of olivine-I and cores of olivine-II (Fig. 3a). They occur as single grains or clusters of several crystals. They vary in size (25-400 $\mu \mathrm{m})$, colour (emerald-green to greyish-green) and shape (round to euhedral-subhedral). Many of them are intimately associated with the carbonatechloride material, which forms coating on surfaces and inclusions inside clinopyroxene grains (Fig. 3). As olivine shows intensive fracturing around clinopyroxene inclusions and clinopyroxene has cleavage planes (Fig. 3a), such inclusions (Fig. 3b) are likely of secondary origin. The clinopyroxene inclusions (Mg\# 87.2-94.8 mol\%) are in $\mathrm{Mg}-\mathrm{Fe}$ equilibrium with the host olivine $\mathrm{Fo}_{86.3-93}$, and characterised by low $\mathrm{Al}_{2} \mathrm{O}_{3}(0.5-2.9 \mathrm{wt} \%), \mathrm{TiO}_{2}(0-$ $0.28 \mathrm{wt} \%)$ and high $\mathrm{CaO}(18.9-23.8 \mathrm{wt} \%), \mathrm{Na}_{2} \mathrm{O}(0.65-$ $2.55 \mathrm{wt} \%)$ and $\mathrm{Cr}_{2} \mathrm{O}_{3} \quad(0.6-2.8$ wt\%) contents. Individual crystals show fine-scale compositional zoning, with a general pattern of $\mathrm{MgO}$ and $\mathrm{CaO}$ increase, and $\mathrm{Na}_{2} \mathrm{O}, \mathrm{Cr}_{2} \mathrm{O}_{3}$ and in some cases $\mathrm{Al}_{2} \mathrm{O}_{3}$, decrease towards the rims. Clinopyroxene in the Udachnaya peridotite xenoliths can also occur as round inclusions in olivine (Fig. 4). Peridotitic clinopyroxene analysed in this and other studies (e.g. Sobolev, 1977) is generally more magnesian (Mg\# 89.5-95.5 mol\%) than clinopyroxene inclusions. The major element compositions of both types are largely overlapped; however, lower-Mg\# clinopyroxene inclusions have different trends on binary diagrams.

Clinopyroxene inclusions are enriched in light rareearth elements (e.g., La = 4-15xPM), but strongly depleted in elements more incompatible than
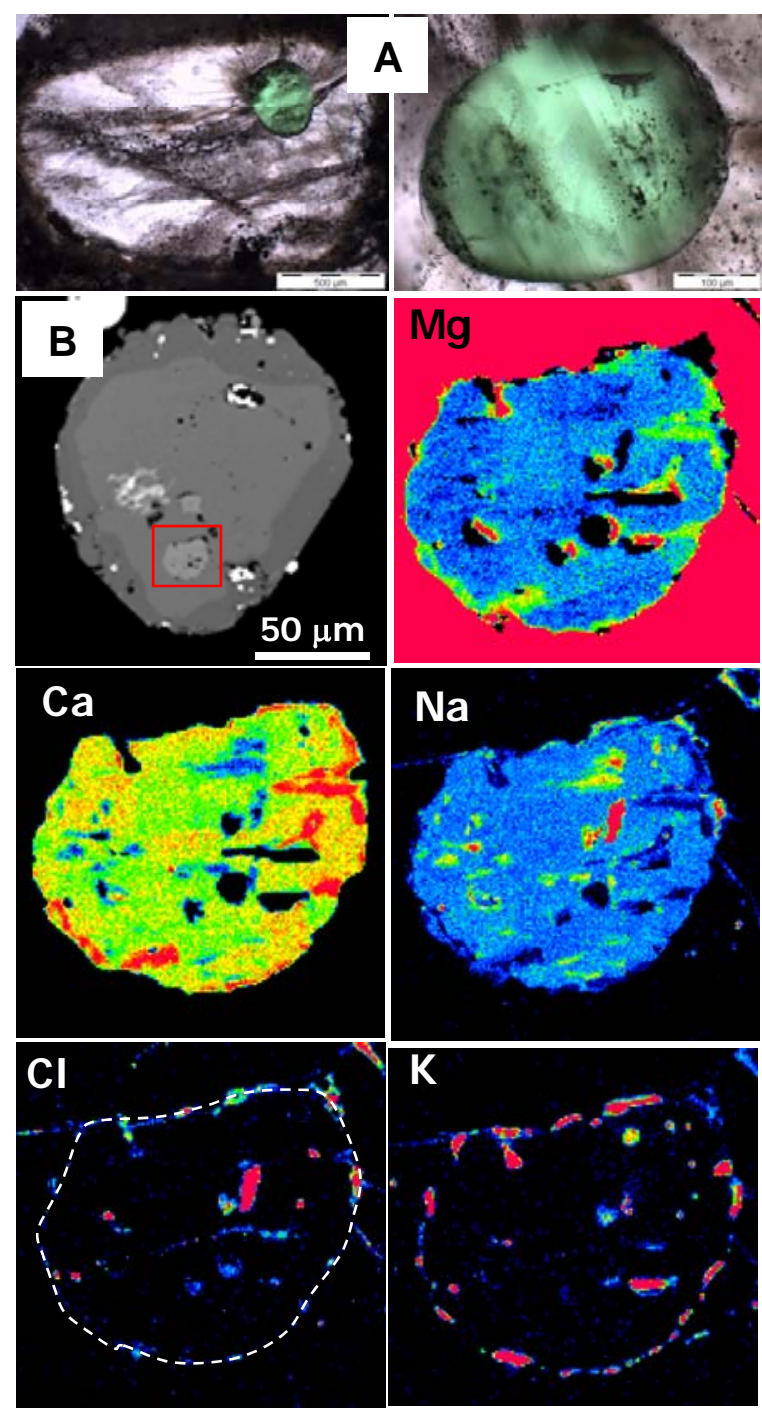

Fig. 3. Clinopyroxene inclusions in kimberlitic olivine cores showing associatiation with alkali-rich carbonate-chloride melt inclusions.

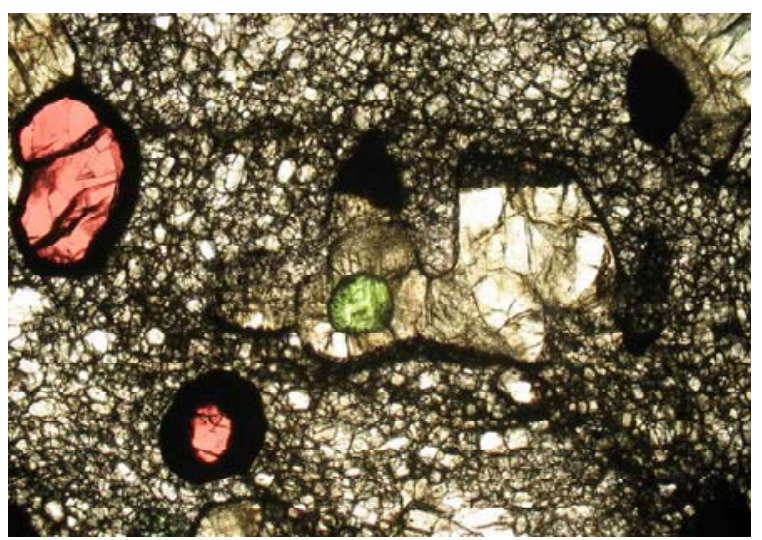

Fig. 4. Clinopyroxene inclusion in olivine from a sheared garnet lherzolite xenolith in the Udachnaya-East pipe kimberlite

La, heavy rare-earth elements (e.g., Yb $=0.3-0.5 x P M$ ) and high-field strength elements (e.g., $\mathrm{Nb}, \mathrm{Zr}, \mathrm{Ti}$ ). Trace element compositions of clinopyroxene inclusions are similar to those from peridotite xenoliths hosted in the same kimberlite, being most similar to clinopyroxene from sheared lherzolite nodules (Fig. $5 a)$. The high pressure origin of high-Ca pyroxene 
inclusions ( $>40 \mathrm{~kb}$ ) is also indicated by their $\mathrm{Na}-$ and Cr-enriched compositions. The assumption of clinopyroxene crystallising from or coexisting (residual) with a hypothetical melt was used in calculating lithophile trace element compositions of such equilibrium melt using published Kd (Johnston and Schwab, 2004). The calculated melt has a lot of resemblance to the Udachnaya-East kimberlites for most elements and their ratios, especially rare earths (Fig. 5b). Simple re-equilibration with the host kimberlite cannot be completely excluded; another explanation supports presence of clinopyroxene, similar to clinopyroxene inclusions, in the mantle source or even high-pressure crystallisation from the protokimberlite melt.
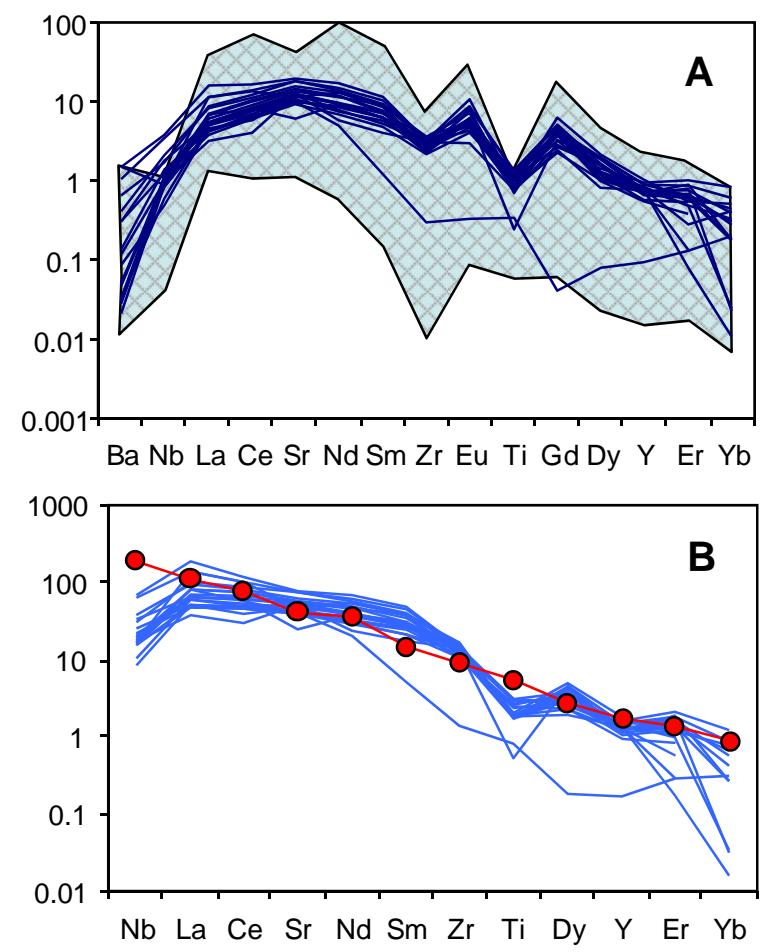

Fig. 5. Trace element PM-normalised compositions of clinopyroxene inclusions (A) and calculated equilibrium melts (B, red) compared to clinopyroxenes from peridotite xenoliths (shaded field) and average Udachnaya-East pipe kimberlite, respectively.

In one case several grains of coexisting ortho- and clinopyroxene were recorded in olivine after heating to $1250^{\circ} \mathrm{C}$ (Fig. 2b). All grains in this assemblage are anhedral and surrounded by a silicate glass with vapour bubbles. The clinopyroxene (Mg\# 87.3-88 mol \%) has higher $\mathrm{TiO}_{2}$ (0.6 $\left.0.9 \mathrm{wt} \%\right)$ and lower $\mathrm{CaO}$ (16.2-17.2 wt\%) abundances in comparison with individual clinopyroxene inclusions.

Conclusions: An unambiguous result of this study is that pyroxene minerals in the Udachnaya-East kimberlite do not form during crystallisation of the parental melt. They are only found as either resorbed macrocrysts or small inclusions in olivine; both types are being very rare and volumetrically insignificant. Both clinopyroxene and orthopyroxene inclusions are compositionally similar to their counterparts in the kimberlite-hosted peridotite xenoliths. This supports their high pressure origin, however, local reactions, producing orthopyroxene and affecting clinopyroxene, cannot be entirely excluded. Thus, virtual absence of both pyroxenes as liquidus minerals put a mafic-ultramafic lineage of the kimberlite parental melt in jeopardy. Instead, we use a pyroxenefree "signature" of kimberlite rocks as another evidence for the kimberlite parental melt being essentially carbonate-chloride composition with dissolved olivine component (Kamenetsky et al., 2007a, 2007b; 2008).

\section{References}

Edgar, A.D. and Charbonneau, H.E., 1993. Melting experiments on a $\mathrm{SiO}_{2}$-poor, $\mathrm{CaO}$-rich aphanitic kimberlite from 5-10 GPa and their bearing on sources of kimberlite magmas. American Mineralogist, 78: 132-142.

Harris, M. et al., 2004. Geochemistry of the Uintjiesberg kimberlite, South Africa: petrogenesis of an offcraton, group I, kimberlite. Lithos, 74: 149-165.

Johnston, A.D. and Schwab, B.E., 2004. Constraints on clinopyroxene/melt partitioning of REE, $\mathrm{Rb}, \mathrm{Sr}, \mathrm{Ti}$, $\mathrm{Cr}$, Zr, and $\mathrm{Nb}$ during mantle melting: First insights from direct peridotite melting experiments at 1.0 GPa. Geochimica Et Cosmochimica Acta, 68: 4949-4962.

Kamenetsky, M.B. et al., 2004. Kimberlite melts rich in alkali chlorides and carbonates: a potent metasomatic agent in the mantle. Geology, 32: 845848.

Kamenetsky, V.S. et al.., 2007a. Chloride and carbonate immiscible liquids at the closure of the kimberlite magma evolution (Udachnaya-East kimberlite, Siberia). Chemical Geology, 237: 384-400.

Kamenetsky, V.S. et al., 2007b. Carbonate-chloride enrichment in fresh kimberlites of the UdachnayaEast pipe, Siberia: A clue to physical properties of kimberlite magmas? Geophysical Research Letters, 34(9): L09316, doi:10.1029/2007GL029389.

Kamenetsky, V.S. et al., 2008. Olivine in the Udachnaya-East kimberlite (Yakutia, Russia): types, compositions and origins. Journal of Petrology, 49: 823-839.

Kopylova, M.G., Matveev, S. and Raudsepp, M., 2007. Searching for parental kimberlite melt. Geochimica et Cosmochimica Acta, 71: 3616-3629.

le Roex, A.P. et at., 2003. Petrogenesis of group I kimberlites from Kimberley, South Africa: evidence from bulkrock geochemistry. Journal of Petrology, 44: 22612286.

Mitchell, R.H., 1986. Kimberlites: mineralogy, geochemistry and petrology. Plenum Press, New York, 442 pp.

Price, S.E. et al., 2000. Primitive magma from the Jericho Pipe, NWT, Canada: Constraints on primary kimberlite melt chemistry. Journal of Petrology, 41: 789-808.

Sobolev, N.V., 1977. Deep-seated inclusions in kimberlites and the problem of the composition of the upper mantle. American Geophysical Union, Washington, D.C., 279 pp.

Sobolev, A.V. et al., 1989. Fluid and melt compositions in lamproites and kimberlites based on the study of inclusions in olivine. In: J. Ross, et al. (Eds), Kimberlites and related rocks: their composition, occurrence, origin and emplacement. Blackwell Scientific Publications, Sydney, pp. 220-241. 